\title{
Hubungan Kecerdasan Linguistik Dengan Hasil Belajar Matematika Siswa Kelas Xi SMA Taman Siswa Lubuk Pakam
}

\author{
May Fitriana Hasibuan \\ Dosen Program Studi Komputerisasi Akuntansi \\ Politeknik Trijaya Krama Medan, Jl. Iskandar Muda No. 1 Medan, Sumatera Utara 20154, Indonesia \\ Email: may_h27@ymail.com
}

\begin{abstract}
This study aims to determine whether there is a significant positive relationship between linguistic intelligence and students 'mathematics learning outcomes and to find out how the results of students' linguistic intelligence are seen from verbal tests. This research was conducted at the Taman Siswa Lubuk Pakam Private High School Learning Year 2018/219. The population in this study were all SMA XI IPA Taman Siswa Lubuk Pakam Learning Year 2018/2019 which amounted to 200 people consisting of five classes. The study sample was determined randomly, so the selected class XI IPA-2. The instrument used in this study was a verbal test of 40 items and a test of mathematics learning outcomes of 20 items. This test is in the form of multiple choices, each of which is asked for responses by 3 validators and has been tested. Before testing the hypothesis, the test requirements for data analysis were carried out, namely the normality test and homogeneity test. From the calculation of the normality test using the liliefors standard error test obtained $\mathrm{L}_{0}=0.1051<\mathrm{L}_{\mathrm{t}}=0.140$ because $\mathrm{L}_{0}<\mathrm{L}_{\mathrm{t}}$ then the data comes from populations that are normally distributed. Furthermore, the homogeneity test was obtained by $\mathrm{F}_{\mathrm{h}}=1.09<\mathrm{F}_{0.05(39.39)}=1.80$, the data population variance came from homogeneous populations. Then based on the linearity test and regression significance test, it was found that the regression model $Y=26,46+0,51 X$ had a linear and significant relationship with the level of $c=0.05$. Based on the results of data analysis using the correlation coefficient obtained $r_{X Y}=0.53$. This means that there is a positive relationship between linguistic intelligence and student mathematics learning outcomes, then hypothesis testing is done with $t$ statistics and obtained $t_{h}=3.85$ which is greater than $t_{t}=1.6449$ at level $a=0.05$ and $d k=28$. This means that besides there is a positive relationship there is also a significant relationship between linguistic intelligence and learning outcomes in mathematics. Thus the research hypothesis is accepted, namely there is a significant positive relationship between linguistic intelligence and the mathematics learning outcomes of class XI students of Taman Siswa Lubuk Pakam Private High School Learning Year 2018/2019. Based on the data from the linguistic intelligence test using verbal tests consisting of 8 parts, the lowest score of 14 was obtained with the percentage of correct answers $35 \%$ and the highest score of 32 with the percentage of correct answers $80 \%$. Then the percentage of students who answered correctly from each verbal intelligence test, namely synonym test $79 \%$ antonym test $73.5 \%, 55 \%$ word group test, $54 \%$ word relationship matching test, $62.5 \%$ vocabulary test, analogy test $51 \%, 54 \%$ similarity test, $54 \%$ analytical ability test.
\end{abstract}

Keywords: Linguistic Intelligence, Mathematics Learning Outcomes

\section{Pendahuluan}

Dalam dunia pendidikan banyak terjadi ketidak sesuaian antara perencanaan dengan hasil yang di proleh. Ketidak berhasilan ini dapat dilihat dari rendahnya hasil belajar matematika yang dicapai oleh siswa. Rendahnya hasil belajar siswa pada pelajaran matematika tidak terlepas dari kemampuan guru dalam mengajarkan siswanya. Selama ini sebagian besar guru hanya mengajarkan dengan model yang sesuai dengan kecerdasan guru, sehingga tidak dirasakan banyak manfaatnya oleh anak didik.

Kecerdasan dan kecakapan yang dimiliki individu-individu tentunya tidak sama, sehingga akan membedakan masing-masing individu itu sendiri. dalam proses belajar mengajar dirasakan guru lebih banyak menilai kecerdasan anak didik. semata-mata pada kemampuan logika (matematis) sehingga mereka menganggap kemampuan logika (matematis) sebagai tolak ukur kecerdasan anak didik. praktisi pendidikan Dr. Seto Mulyadi (http://www.kompas.com) mengatakan bahwa : sistem pengajaran yang mengukur tingkat kecerdasan anak didik semata-mata pada kemampuan logika (matematis) perlu di revisi. karena kecerdasan itelektual tidak hanya mencakup kemampuan logika (matematis) tetapi juga bisa dilihat dari aspek lingustik atau kecerdasan linguistik. Selama ini kecerdasan linguistik atau kemampuan berbahasa dianggap hanya sebagai keahlian pada bidang sosial, karena banyak profesi terkait, misalnya ahli bahasa, penulis, politis, atau ahli hukum. hal ini benar, tapi untuk kecerdasan linguistik juga sangat penting, 
khususnya kemampuan dalam bahasa. Thomas Armstrong (2003:100) mengatakan : "meskipun secara umum dipandang sebagai keahlian pada ilmu-ilmu humaniora kecerdasan linguistik juga dibutuhkan dalam pengajaran matematika dan ilmu pasti.

Jika siswa kesulitan dalam hal bahasa maka ia juga akan mengalami kesulitan dalam belajar matematika. kesulitan ini dapat mempengaruhi keberhasilan siswa dari matematika dan dapat mengakibatkan hasil belajar matematika siswa juga rendah.

\section{Kajian Pustaka}

\subsection{Kecerdasan Linguistik}

Kecerdasan linguistik merupakan kemampuan berbahasa dan menggunakan kata-kata secara efektif baik secara lisan maupun tulisan. Dalam kehidupan, kecerdasan linguistik memberikan kemampuan dalam berbicara, mendengarkan, membaca berbagai simbol dan tanda, karya tulis hingga karya sastra yang bermutu tinggi. Kecerdasan linguistik tidak hanya meliputi kemampuan menulis atau membaca. Kecerdasan ini juga mencakup kemampuan berkomunikasi. Albert Mehrabian (dalam Adi W. Gunawan, 204:107) mengatakan bahwa:

Kita berkomunikasi dengan menggunakan tiga komponen. Tiga komponen itu adalah kata yang digunakan, suara dan intonasi nada yang digunakan saat mengucapkan kata-kata tersebut, dan bagaimana kita menggunakan ekspresi wajah dan bahasa tubuh untuk menegaskan apa yang kita sampaikan.

\subsection{Kecerdasan Linguistik dalam Matematika}

Dalam pengajaran matematika, selalu menggunakan bahasa matematika, simbol-simbol yang digunakan harus dapat dicerna atau dimengerti dengan baik oleh siswa yang membelajarinya.

Sahat Saragih (1996:13) mengatakan bahwa:

Matematika merupakan ilmu yang terstruktur yang sarat dengan simbol-simbol, sehingga matematika dapat dikatakan sebagai bahasa simbol. Oleh karenanya untuk mempelajari matematika diperlukan kemampuan berbahasa yang mencakup kemampuan membaca, kemampuan memahami bacaan, yang selanjutnya diharapkan siswa mampu menyusun kembali dalam bahasanya sendiri sesuai dengan tingkat perkembangan intelektualnya. Dengan demikian dapat dikatakan kecerdasan linguistik khususnya kemampuan dalam bahasa dan membaca mempunyai peranan yang sangat penting dalam matematika dan sangat menentukan keberhasilan siswa dalam mempelajari matematika.

\subsection{Pengertian Belajar Matematika}

Belajar merupakan suatu proses yang ditandai dengan adanya perubahan pada diri seseorang. Purwanto (1991:27) mengartikan bahwa "belajar adalah suatu perubahan tingkah laku dimana perubahan tingkah laku itu terjadi melalui latihan dan pengalaman dan bersifat relative menetap. Perubahan-perubahan itu tentu akan mempengaruhi siswa jika proses belajar itu dialami sendiri oleh siswa, karena itu terjadinya belajar atau tidak tergantung pada siswa itu sendiri.

\subsection{Hasil Belajar Matematika}

Proses belajar mencapai puncak pada hasil belajar. Setiap proses belajar mengajar selalu menghasilkan hasil belajar, karena hasil belajar merupakan indikator untuk mengukur keberhasilan siswa dalam proses belajar. Untuk mengukur tingkat keberhasilan belajar dapat dilakukan melalui Tes Hasil Belajar (THB). Nasution dan Suryanto (2000:4) menyatakan "Tes Hasil Belajar (THB) adalah alat ukur yang mampu menentukan kemampuan seseorang setelah mengikuti pembelajaran". Langkah selanjutnya dengan melakukan evaluasi terhadap pengukuran hasil belajar.

\section{Metode}

\subsection{Teknik Analisis Data}

a. Uji Normalitas

Uji normalitas di adakan untuk mengetahui normal atau tidaknya populasi peneliti tiap variabel peneliti.

Penguji ini digunakan dengan menggunakan uji liliefors, langkah-langkah yang dilakukan sebagai berikut:

1. Pengamatan $X_{1}, X_{2}, X_{3}, \ldots, X_{n}$ dijadikan bilangan baku $Z_{1}, Z_{2}, Z_{3}, \ldots, Z_{n}$ dengan rumus: $Z_{1} \bigotimes \frac{X, \nabla \bar{X}}{S}$

Dimana:

$\bar{X}=$ rata-rata

$\mathrm{S}=$ simpangan baku sampel 
2. Untuk tiap bilanga baku ini dengan menggunakan daftar distribusi normal baku kemudian dihitung peluang $F\left(Z_{I}\right) \otimes P\left(Z \otimes Z_{i}\right)$.

3. Selanjutnya dihitung proporsi $Z_{1}, Z_{2}, Z_{3}, \ldots, Z_{n}$ yang lebih kecil atau sama dengan $Z_{i}$, jika proporsi ini dinyatakan dengan $S\left(Z_{i}\right)$ 囚 $\frac{\text { banyaknya }_{1}, Z_{2}, Z_{3}, \ldots, Z_{n} \text { yang } \otimes Z_{i}}{n}$

4. Menghitung selisih $F\left(Z_{i}\right)-S\left(Z_{i}\right)$ kemudian menentukan harga mutlaknya.

5. Ambil harga mutlak yang terbesar disebut $\left(L_{0}\right)$. Untuk menerima atau menolak hipotesis, kita bandingkan $L_{0}$ dengan nilai kritis L yang diambil dari daftar, untuk taraf nyata $\otimes \otimes 0,005$. Dengan kriteria:

Jika $L_{0}<L_{\text {tabel }}$ maka sampel berdistributif normal.

Jika $L_{0}>L_{\text {tabel }}$ maka sampel tidak berdistributif normal.

\section{b. Uji Homogenitas}

Untuk menguji apakah data homogen atau tidak, digunakan uji homogenitas (uji kesamaan dua varians)

1. Dalam hal ini yang diuji adalah kesamaan varians kedua populasi sampel.

$H_{0}: \nabla_{x}^{2} \otimes \nabla_{y}^{2}$ (data berasal populasi yang bervarians sama)

$H_{a}: \bigotimes_{x}^{2} \bigotimes \nabla_{y}^{2}$ (data berasal dari populasi yang bervarians berbeda)

2. Kesamaan varians ini akan diuji dengan rumus: $F \otimes \frac{\text { VariansTerbesar }}{\text { VariansTerkecil }}$

3. Kriteria penguji:

Jika $F_{\text {hitung }}<F_{\text {tabel }}$ maka $H_{a}$ ditolak dan $H_{0}$ diterima, jika $F_{\text {hitung }} \geq F_{\text {tabel }} H_{a}$ diterima $H_{0}$ ditolak. Dengan dk pengambilan $=\left(\mathrm{n}_{1}-1\right)$ dan dk penyebut $=\left(\mathrm{n}_{2}-1\right)$ dengan taraf nyata $\mathrm{a}=0,005$

c. Uji Hipotesis

1. Hipotesis yang akan diuji adalah:

$H_{0}: \mu_{1}=\mu_{2}$

$H_{a}: \mu_{1}>\mu_{2}$

2. Alternatif pemilihan uji t

Untuk menguji hipotesis digunakan uji t, uji t digunakan karena $\bigotimes_{x} \nabla_{y}$ dan $\triangle$ tidak diketahui. Maka digunakan rumus uji t yaitu:

$$
t_{\text {hitung }} \otimes \frac{\overline{X_{x}} \otimes \overline{X_{y}}}{S \sqrt{\frac{1}{n_{x}} \otimes \frac{1}{n_{y}}}}
$$

Sudjana (1992:239)

$$
\text { Dengan } S^{2} \otimes \frac{\left(n_{x} \otimes 1\right) S_{x}^{2} \otimes\left(n_{y} \otimes 1\right) S_{y}^{2}}{n_{x} \otimes n_{y} \otimes 2}
$$

Dimana:

$\mathrm{n}_{\mathrm{x}} \quad=$ jumlah sampel kelas eksperimen

$\begin{array}{ll}\mathrm{n}_{\mathrm{y}} & =\text { jumlah sampel kelas kontrol } \\ X_{x} & =\text { rata-rata kelas eksperimen }\end{array}$ 


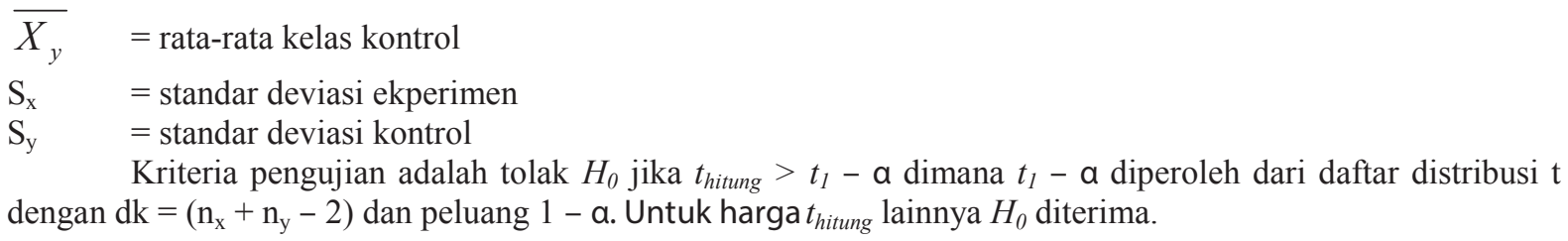

\section{Hasil Dan Pembahasan}

\subsection{Deskripsi Data Penelitian}

Berdasarkan tes kecerdasan linguistik dan tes hasil belajar matematika siswa yang diujikan maka diperoleh skor siswa sebagai berikut :

Tabel 1.

Perolehan Skor Kedua Instrumen Penelitian

\begin{tabular}{|c|c|c|c|c|c|c|c|c|c|c|c|c|}
\hline \multirow{2}{*}{$\begin{array}{l}\text { Respon } \\
\text { den }\end{array}$} & \multicolumn{8}{|c|}{ Tes Verbal } & \multirow{2}{*}{$\begin{array}{c}\text { Jumlah } \\
\text { Skor }\end{array}$} & \multicolumn{2}{|c|}{$\begin{array}{c}\text { Tes Hasil } \\
\text { Belajar }\end{array}$} & \multirow{2}{*}{$\begin{array}{c}\text { Jumlah } \\
\text { Skoor }\end{array}$} \\
\hline & I & II & III & IV & $\mathrm{v}$ & VI & VII & VIII & & $\begin{array}{l}\mathrm{KD} \\
1\end{array}$ & $\begin{array}{l}\mathrm{KD} \\
2\end{array}$ & \\
\hline $\mathrm{A}$ & 4 & 3 & 1 & 3 & 4 & 3 & 4 & 2 & 24 & 7 & 4 & 11 \\
\hline B & 3 & 3 & 2 & 2 & 3 & 1 & 1 & 1 & 16 & 4 & 5 & 9 \\
\hline $\mathrm{C}$ & 3 & 2 & 1 & 3 & 1 & 1 & 1 & 2 & 14 & 3 & 5 & 8 \\
\hline $\mathrm{D}$ & 5 & 5 & 3 & 2 & 4 & 3 & 3 & 3 & 28 & 4 & 8 & 12 \\
\hline $\mathrm{E}$ & 2 & 3 & 3 & 1 & 3 & 2 & 2 & 1 & 17 & 5 & 4 & 9 \\
\hline$F$ & 4 & 3 & 2 & 1 & 2 & 1 & 1 & 4 & 18 & 6 & 2 & 8 \\
\hline $\mathrm{G}$ & 5 & 5 & 4 & 3 & 1 & 2 & 5 & 5 & 30 & 8 & 6 & 14 \\
\hline $\mathrm{H}$ & 4 & 3 & 4 & 3 & 1 & 1 & 1 & 1 & 18 & 7 & 1 & 8 \\
\hline I & 5 & 4 & 2 & 2 & 1 & 1 & 3 & 2 & 20 & 9 & 3 & 12 \\
\hline $\mathrm{J}$ & 5 & 5 & 2 & 4 & 3 & 1 & 4 & 2 & 26 & 9 & 6 & 15 \\
\hline $\mathrm{K}$ & 4 & 3 & 3 & 2 & 2 & 3 & 2 & 2 & 21 & 5 & 5 & 10 \\
\hline $\mathrm{L}$ & 3 & 2 & 4 & 4 & 3 & 2 & 1 & 3 & 22 & 4 & 7 & 11 \\
\hline $\mathrm{M}$ & 4 & 3 & 4 & 3 & 2 & 3 & 3 & 1 & 23 & 4 & 8 & 12 \\
\hline $\mathrm{N}$ & 5 & 5 & 2 & 1 & 5 & 3 & 2 & 5 & 28 & 7 & 2 & 9 \\
\hline 0 & 4 & 5 & 1 & 2 & 5 & 1 & 4 & 1 & 23 & 6 & 4 & 10 \\
\hline $\mathrm{P}$ & 3 & 3 & 3 & 1 & 4 & 4 & 4 & 2 & 24 & 10 & 4 & 14 \\
\hline$Q$ & 2 & 3 & 3 & 2 & 2 & 2 & 2 & 1 & 17 & 5 & 7 & 12 \\
\hline R & 5 & 3 & 1 & 4 & 3 & 2 & 4 & 3 & 25 & 9 & 4 & 13 \\
\hline $\mathrm{S}$ & 5 & 5 & 2 & 3 & 2 & 3 & 3 & 3 & 26 & 9 & 4 & 13 \\
\hline $\mathrm{T}$ & 5 & 5 & 2 & 1 & 5 & 2 & 4 & 4 & 28 & 5 & 6 & 11 \\
\hline $\bar{U}$ & 2 & 3 & 2 & 1 & 4 & 3 & 2 & 3 & 20 & 4 & 6 & 10 \\
\hline $\mathrm{V}$ & 4 & 3 & 3 & 4 & 4 & 2 & 3 & 3 & 26 & 5 & 4 & 9 \\
\hline $\mathrm{W}$ & \begin{tabular}{|l|}
3 \\
\end{tabular} & 3 & 5 & 4 & 2 & 3 & 2 & 3 & 25 & 10 & 4 & 14 \\
\hline $\mathrm{X}$ & 5 & 5 & 3 & 2 & 3 & 4 & 2 & 2 & 26 & 3 & 7 & 10 \\
\hline $\mathrm{Y}$ & 3 & 3 & 3 & 2 & 2 & 1 & 2 & 2 & 18 & 7 & 5 & 12 \\
\hline$z$ & 4 & 4 & 2 & 3 & 2 & 3 & 4 & 4 & 26 & 9 & 1 & 10 \\
\hline $\mathrm{AA}$ & 5 & 5 & 2 & 3 & 4 & 3 & 3 & 3 & 28 & 4 & 8 & 12 \\
\hline $\mathrm{AB}$ & 4 & 3 & 3 & 5 & 4 & 3 & 2 & 3 & 27 & 4 & 8 & 12 \\
\hline $\mathrm{AC}$ & 5 & 5 & 4 & 3 & 3 & 3 & 2 & 3 & 28 & 8 & 5 & 14 \\
\hline $\mathrm{AD}$ & 4 & 4 & 3 & 2 & 3 & 2 & 2 & 3 & 23 & 5 & 5 & 10 \\
\hline $\mathrm{AE}$ & 3 & 2 & 1 & 4 & 4 & 3 & 5 & 4 & 26 & 9 & 3 & 12 \\
\hline $\mathrm{AF}$ & 5 & 4 & 2 & 3 & 3 & 5 & 3 & 3 & 28 & 8 & 7 & 15 \\
\hline $\mathrm{AG}$ & 5 & 3 & 3 & 4 & 4 & 4 & 2 & 1 & 26 & 7 & 5 & 12 \\
\hline $\mathrm{AH}$ & 4 & 4 & 3 & 3 & 4 & 3 & 3 & 4 & 28 & 2 & 8 & 10 \\
\hline $\mathrm{AI}$ & 5 & 4 & 4 & 4 & 5 & 3 & 2 & 3 & 30 & 6 & 3 & 9 \\
\hline $\mathrm{AJ}$ & 2 & 2 & 3 & 2 & 3 & 2 & 1 & 2 & 17 & 2 & 7 & 9 \\
\hline $\mathrm{AK}$ & 4 & 5 & 4 & 3 & 5 & 4 & 2 & 3 & 30 & 9 & 7 & 16 \\
\hline $\mathrm{AL}$ & 3 & 3 & 4 & 3 & 4 & 4 & 4 & 3 & 28 & 10 & 3 & 13 \\
\hline $\mathrm{AM}$ & 3 & 4 & 3 & 2 & 3 & 3 & 4 & 4 & 26 & 8 & 7 & 15 \\
\hline $\mathrm{AN}$ & 5 & 5 & 4 & 4 & 3 & 3 & 4 & 4 & 32 & 8 & 5 & 13 \\
\hline
\end{tabular}

Keterangan :

I $\quad$ : Tes Sinonim

II : Tes Antoonim

III : Tes Kelompok Kata

IV : Tes Pendanaan hubungan kata

V :Tes Perbendaharaan Kata

VI : Tes Analogi

VII : Tes Similariti

VIII : Tes Kemampuan Analitik

KD1 : Kompetensi Dasar 1

KD2 : Kompetensi Dasar 2

Perolehan skor dari kedua instrument penelitian yakni tes kecerdasan linguistik dan tes hasil belajar matematika, kemudian dikonversikan kedalam nilai berstandar 100. Rumus yang digunakan adalah 


$$
\text { Nilai }=\frac{\text { Jumlah skor yang diperoleh }}{\text { Banyaknya item soal }} \times 100
$$

Hasil konversi tersebut dapat dilihat pada lampiran 21 dan 22. Setelah skor dikonversikan ke dalam nilai berstandar 100 maka diproleh nilai rata-rata untuk tes kecerdasan linguistik $X=60,38$ dan standar deviasi $\mathrm{S}_{\mathrm{X}}=$ 11,39 sedangkan nilai rata-rata untuk tes hasil belajar matematika $Y=57,25$ dan standar deviasi $\mathrm{S}_{\mathrm{Y}}=10,86$.

\subsection{Uji Persyaratan Analisis Data}

Sebelum pengujian hipotesis dilakukan, maka data dari hasil penelitian harus memenuhi beberapa persyaratan yang harus dipenuhi yaitu syarat normalitas dan homogenitas.

\section{a. Uji Normalitas}

Untuk uji normalitas data digunakan Uji Normalitas galat baku liliefors. Dengan criteria pengujian apabila $\mathrm{L}_{\mathrm{o}}<\mathrm{L}_{\mathrm{t}}$ dengan taraf signifikan $\mathrm{a}=0,05$ maka sampel berasal dari pulasi yang berdistribusi normal.

Hasil pengujian Normalitas terhadap data kecerdasan linguistik siswa (X) dan data hasil belajar matematika (Y) diperoleh $\mathrm{L}_{0}=0,1051$ sedangkan pada taraf signifikan $\mathrm{a}=0,05$ dan $\mathrm{n}=40$ diperoleh harga $\mathrm{t}_{\mathrm{t}} \mathrm{L}=0,140$. Karena $\mathrm{L}_{\mathrm{o}}<\mathrm{L}_{\mathrm{t}}$ atau $0,1051<0,140$ maka data kecerdasan linguistik siswa $(\mathrm{X})$ dan data hasil belajar matmatika (Y) berasal dari populasi yang berdistribusi normal.

\section{b. Uji Homogenitas}

Untuk homogenitas data digunakan analisis varians. Hasil pengujian homogenitas data kecerdasan linguistik siswa $(\mathrm{X})$ dan data hasil belajar matematika $(\mathrm{Y})$ diperoleh $S_{X}^{2}=129,66$ dan $S_{Y}^{2}=117,88$. Kemudian dengan membandingkan varians $X$ terhadap varians $Y$ diperoleh $F_{h}=1,09$ sedangkan $F_{0,05(39,39)}=1,80$. Karena $F_{h}<F_{0,05}$ $(39,39)$ atau $1,09<1,80$ ini berarti varians dari populasi data kecerdasan linguistik siswa (X) dan data hasil belajar matematika (Y) adalah homogen.

\subsection{Uji Linieritas dan Keberartian Regresi}

Berdasarkan hasil perhitungan analisis regresi sederhana untuk variable hasil belajar matematika atas kecerdasan linguistik siswa diperoleh persamaan regresi $Y=26,46+0,51 X$.

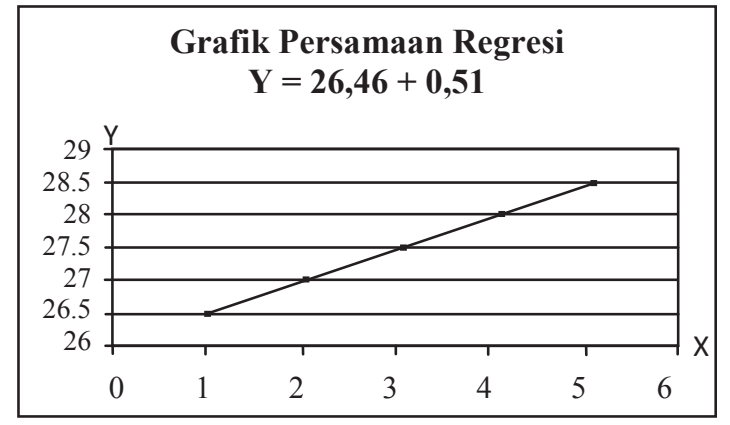

Gambar 1. Grafik Persamaan Regresi $Y=26,46+0,51 X$

Dari gambar 1. terlihat bahwa hubungan antara dua variable dalam penelitian ini yaitu variable $\mathrm{X}$ (kecerdasan linguistic) dan variable Y (hasil belajar matematika) menunjukkan hubungan yang searah. Artinya, jika kecerdasan linguistik (X) makin tinggi maka hasil belajar matematika (Y) juga akan semakin tinggi pula dan sebaliknya, jika kecerdasan linguistic (X) makin rendah maka hasil belajar matematika (Y) juga akan semakin rendah.

Uji signifikansi dan linieritas persamaan regresi tersebut dapat dilihat pada tabel 2.

Tabel 2.

Analisis Varians Untuk Pengujian Signifikansi dan Linieritas Regresi $Y=26,46+0,51 X$

\begin{tabular}{|l|c|c|c|c|c|}
\hline Sumber Varians & Dk & JK & KT & $F_{h}$ & $\begin{array}{c}F_{t} \\
(a=0,05)\end{array}$ \\
\hline Total & 40 & 135700 & & & \\
\hline Regresi (a) & 1 & 131102,5 & & & \\
Regresi (b/a) & 1315,03 & 1315,03 & 15,22 & 4,10 \\
Resi du (sisa) & 1 & 3282,47 & & & \\
\hline
\end{tabular}


Keterangan :

\begin{tabular}{|l|c|r|r|r|r|}
\hline & 38 & & 86,38 & & \\
\hline $\begin{array}{l}\text { Tuna Cocok(TC) } \\
\text { Galat }\end{array}$ & 13 & 249,13 & 19,16 & & \\
& 25 & 3033,33 & 121,33 & 0,16 & 2,14 \\
\hline
\end{tabular}

Dk : Derajat Kebebasan

JK : Jumalh Kuadrat

KT : Kuadrat Tengah

$\mathrm{F}_{\mathrm{h}}: \mathrm{F}$ hitung

$\mathrm{F}_{\mathrm{t}}: \mathrm{F}$ tabel pada $\mathrm{a}=0,05$

Dari tabel 4.2. dapat dilihat bahwa Ft dengan $\mathrm{dk}(13,25)$ pada $a=0,05$ adalah 2,14 sedangkan $\mathrm{n}_{\mathrm{h}}$ Fyang diperoleh adalah 0,16 . Ternyata $F_{h}<F_{t}$ atau $0,16<2,14$ sehingga persamaan regresi tersebut adalah linier.

Selanjutnya untuk uji keberartian regresi $\mathrm{Y}$ atas $\mathrm{X}$ dengan dk $(1,38)$ pada $Y=26,46+0,51 X$ diperoleh $\mathrm{F}_{\mathrm{t}}=$ 4,10 sedangkan $F_{h}=15,22$. Ternyata $F_{h}>F_{t}$ atau 15,22 $>4,10$. Ini berarti bahwa koefisien arah regresi $Y$ atas $X$ signifikan pada taraf $a=0,05$.

Dengan demikian dapat disimpulkan bahwa persamaan regresi $Y=26,46+0,51 X$ mempunyai hubungan yang linier dan signifikan pada taraf $a=0,05$.

\subsection{Uji Signifikansi Korelasi}

Kekuatan hubungan antara kecerdasan linguistik siswa dan hasil belajar matematika ditunjukkan oleh koefisien korelasi $r_{X Y}=0,53$. Kemudian uji signifikansi korelasi dapat dilihat pada tabel 4.3.

Tabel 3.

Uji Signifikansi Hubungan Kecerdasan Linguistik Siswa Dengan Hasil Belajar Matematika Siswa

\begin{tabular}{|c|c|c|c|c|c|c|}
\hline Variabel & $\mathrm{N}$ & $\mathrm{R}$ & Kuadrat $\mathrm{r}$ & $\mathrm{dk}$ & $t_{\square}$ & $t_{t}(\mathrm{a}=0,05)$ \\
\hline $\mathrm{X}$ dan Y & 40 & 0,53 & 0,2809 & 38 & 3,85 & 1,6449 \\
\hline
\end{tabular}

Keterangan:

$\mathrm{X} \quad$ : Kecerdasan linguistik siswa

Y : Hasi belajar matematika siswa

n : Jumlah sampel

r : Koefisien korelasi

$r^{2} \quad:$ Koefisien determinasi

$\mathrm{dk} \quad$ : Derajat kebebasan

$t_{\square} \quad:$ t hitung

$t_{t} \quad:$ t tabel

Berdasarkan analisis koefisien korelasi tersebut disimpulkan bahwa koefisien korelasi antara kecerdasan linguistik siswa (X) dengan hasil belajar matematika (Y) sebesar 0,53 adalah signifikan. Dari perhitungan uji signifikansi korelasi dengan menggunakan statistik $t$ diperoleh $t_{\square}=3,85$ sedangkan $t_{t}=1,6449$ ternyata $t_{\square}>t_{t}$ atau 3,85 > 1,6449. Dengan demikian hipotesis nol (HO) yang menyatakan tidak terdapat hubungan positif yang signifikan antara kecerdasan linguistik siswa (X) dengan hasil belajar matematika (Y) ditolak. Sedangkan hipotesis penelitian yang menyatakan terdapat hubungan positif yang signifikan antara kecerdasan linguistik siswa (X) dengan hasil belajar matematika (Y) diterima.

Koefisien determinasi adalah kuadrat dari koefisien korelasi X dan Y yaitu sebesar 0,2809. Ini menunjukkan bahwa $28,09 \%$ variasi yang terjadi pada hasil belajar matematika dapat dijelaskan oleh kecerdasan linguistik melalui regresi $Y=26,46+0,51 X$

\subsection{Hasil Tes Kecerdasan Linguistik}

Berdasarkan hasil tes kecerdasan linguistik yang mempergunakan tes verbal yang terdiri dari 8 bagian yaitu:

I : Tes sinonim

II $\quad$ : Tes antonim 
III : Tes kelompok kata

IV : Tes padanan hubungan kata

V : Tes perbendaharaan kata

VI : Tes analogi

VII : Tes similarity

VIII : Tes kemampuan analitik

Maka diperoleh skor terendah 14 dengan persentase jawaban yang benar 35\% dan skor tertinggi 32 dengan persentase jawaban yang benar $80 \%$. Kemudian diperoleh persentase siswa yang menjawab dengan benar dari masing-masing tes kecerdasan verbal yaitu dapat dilihat pada tabel 4 .

Tabel 4

Data Persentase Tes Kecerdasan Linguistik

\begin{tabular}{|l|l|l|l|l|l|l|l|l|}
\hline Tes Verbal & I & II & III & IV & V & VI & VII & VIII \\
\hline Persentase & $79 \%$ & $73,5 \%$ & $55 \%$ & $54 \%$ & $62,5 \%$ & $51 \%$ & $54 \%$ & $54 \%$ \\
\hline
\end{tabular}

Dari tabel persentase diatas terlihat bahwa siswa tertinggi menjawab benar pada tes I yaitu tes sinonim dengan persentase sebesar 79\%. Sedangkan siswa terendah menjawab benar pada tes VI yaitu tes analogi dengan persentase sebesar $51 \%$.

\subsection{Pembahasan Hasil Penelitian}

Penelitian ini bertitik tolak dari pernyataan apakah ada hubungan yang positif signifikan antara kecerdasan linguistik siswa dengan hasil belajar matematika siswa kelas XI SMA Taman Siswa Medan Tahun Pelajaran 2018/2019. Hasil penelitian ini mengungkapkan bahwa ada hubungan yang positif signifikan antara kecerdasan lingustik siswa dengan hasil belajar matematika siswa. Dimana korelasi yang dihasilkan sebesar $\mathrm{r}_{\mathrm{XY}}=0,53$ pada taraf $a=0,05$. Dengan kata lain dapat diartikan makin baik kecerdasan linguistik siswa maka hasil belajar matematika akan semakin baik pula. Dengan demikian hipotesis penelitian yaitu " Ada hubungan positif yang signifikan antara kecerdasan linguistik siswa dengan hasil belajar matematika siswa kelas XI SMA Taman Siswa Medan Tahun Pelajaran 2018/2019 " diterima. Berdasarkan data dari hasil penelitian diperoleh skor terendah untuk tes kecerdasan linguistik adalah 14 dengan persentase jawaban benar sebesar 35\%. Kemudian dari 8 jenis tes verbal yang diujikan ke 40 responden ternyata tes yang terendah dijawab benar oleh siswa adalah tes VI yaitu tes analogi dengan persentase sebesar 51\%. Kontribusi kecerdasan linguistik siswa yang diberikan pada hasil belajar matematika siswa sebesar 28,09\%. Karena besarnya kontribusi kecerdasan linguistik siswa hanya sebesar $28,09 \%$ dapat diambil kesimpulan bahwa tinggi rendahnya hasil belajar matematika siswa tidak hanya dipengaruhi oleh kecerdasan linguistik saja tetapi juga dapat dipengaruhi oleh factor-faktor lain diluar penelitian ini, baik itu berasal dari diri siswa (faktor internal) yang meliputi minat, bakat, kecerdasan, motivasi maupun dari luar (faktor eksternal) yang meliputi lingkungan belajar, guru, sarana dan prasarana, status ekonomi dan lain-lain. Untuk mengetahui hubungan dari faktor-faktor lain tersebut terhadap hasil belajar matematika tentu memerlukan penelitian yang lebih spesifik lagi. Namun demikian peneliti mengakui kekurangan dari hasil penelitian ini, antara lain terdapatnya dua butir soal yang digunakan pada tes hasil belajar yang mempunyai daya beda jelek, keterbatasan ilmu yang peneliti miliki, kurangnya sumber yang menjadi acuan, tidak adanya analisis lebih lanjut terhadap hasil tes dan objektivitas penelitian yang belum sempurna.

\section{Kesimpulan}

1. Ada hubungan positif yang signifikan kecerdasan linguistik siswa dengan hasil belajar siswa khususnya pada pook bahasan Fungsi Komposisi dan Fungsi Invers dengan koefisien korelasi sebesar $r_{X Y}=0,53$ siswa kelas XI SMA Taman Siswa Medan Tahun Pelajaran 2018/2019 artinya apabila kecerdasan linguistik makin tinggi maka hasil belajar matematika juga semakin tinggi pula

2. Hasil tes kecerdasan linguistik diperoleh skor terendah 14 dengan persentase jawaban yang benar $35 \%$ dan skor tertinggi 32 dengan persentase jawaban yang bener $80 \%$. Kemudian diperoleh persentase siswa yang menjawab dengan benar dari masing-masing tes kecerdasan verbal yaitu tes sinonim $79 \%$, tes antonim $73,5 \%$, tes kelompok kata 55\%, tes padanan hubungan kata 54\%, tes perbendaharaan kata $62,5 \%$, tes analogi $51 \%$, tes similariti 54\%, tes kemampuan analitik 54\%. 
3. Kecerdasan linguistik memberikan kontribusi sebesar $28,09 \%$ terhadap hasil belajar matematika siswa kelas XI SMA Taman Siswa Medan Tahun Pelajaran 2018/2019 artinya sumbangan kecerdasan linguistik terhadap hasil belajar matematika adalah $28,09 \%$ sedangkan sisanya $71,91 \%$ berasal dari faktor lain dimana pada kesempatan ini tidak diteliti.

\section{Referensi}

[1] Armstrong, Thomas,(2003),Sekolah Para Juara:Menerapkan Multiple Intelegences Di Dunia Pendidikan, Penerbit Kaifa, Bandung.

[2] Gunawan, Adi W,(2003),Born to Be a Genius, Penerbit Gramedia Pustaka Utama, Jakarta.

[3] Saifullah, Ach dan Maulana,Nine Adien,(2005),Melejitkan Potensi Kecerdasan Anak, Penerbit Kata Hati, Jogjakarta.

[4] Saragih, S, (1994), Pengaruh Jenis Kelamin, Kemampuan Verbal Terhadap Prestasi Belajar Matematika Siswa Kelas I SMA Negeri Se Kodya Medan, Laporan Hasil Penelitian, FMIPA IKIP MEDAN

[5] Sudjana, (1992), Metode Statistika, Penerbit Tarsito, Bandung

[6] Purwanto,N.M,(1991),Psikologi Pendidikan, Penerbit Remaja Rosdakarya, Bandung 